\title{
Corporate Staff Identity as a Factor of Increasing Labor Productivity
}

\author{
Lyutsiya Mugtabarovna Gaisina
}

Eduard Sagidullovich Gareev

Nika Eduardovna Valitova

Ufa State Petroleum Technological University, Russia, Republic of Bashkortostan, 450062, Ufa, Kosmonavtov Str., 1

Nursafa Gafurovna Khairullina

Tyumen State Oil and Gas University, Volodarskogo Street, 38, Tyumen, 625000, Russia

\section{Oksana Vyacheslavovna Ustinova}

Tyumen State University of Architecture and Civil Engineering, Lunacharskogo Street, 2, Tyumen, 625001, Russia

\section{Doi:10.5901/mjss.2015.v6n5p274}

\section{Abstract}

Corporate identity affects the efficiency of any organization due to the fact that it increases the group solidarity and highly motivates every member of a company. It also much improves the discipline of the staff. The given article is devoted to the scientific approaches to the idea of the corporate identity of the staff of a company as well as to the analysis of the results of the research of the process of the corporate identity formation at a large retailer company. As a result of the research the author have come to the conclusions concerning the problems with the level of the estimation of the top management by the workers and the system of education of the company members. The solution of these problems can greatly improve the situation with the corporate identity at the company.

Keywords: corporate culture, corporate identity of the staff, formation of the corporate identity of the staff.

\section{Introduction}

Formation of the corporate identity of the staff is based on the regulations of the corporate culture, which influence the behavior of the workers in the way, which makes them patriots of their company Most of the modern companies consider corporate culture as a very powerful strategic instrument, allowing them to motivate different department of the company as well as each of its' members to the achieving of the company's goals, to improve of the interaction between the departments and to make each of the employees more active and creative when working at the company's problems. The corporate culture of an organization is one of the mechanisms of coordination of individual interests and goals and making them coincide with the strategic goals of the company, thus making a common culture space, which includes corporate values, norms and models of corporate behavior, accepted by all the employees (Silin and Khairullina, 2004; Gaisina, 2014).

The term has been used in management since the late 1970-s. It's thought to have appeared due to the contradictions between the Western system of management based on the competition between the employees and the Japanese concept of an effective organization were team work is more preferable.

Research in the field of is "the culture of an organization" closely connected with the works of such world famous sociologists as M. Weber and K. Levin, who have made a great contribution into the understanding of an industrial enterprise as a kind of social community, as well as on the works of T. Parsons, who has suggested the AGIL (Adaptation - Achievement-Integration - Ligitimacy) sociological concept of company, which considers the interrelation between the corporate culture and the results of its' activity. R.Moran has suggested to investigate the corporate culture of an organization on the basis of ten its' characteristics: systems of communication and the language of communication; understanding of his position and his role in the whole process of work by each of the employees; interpersonal relations in the company; the employees' appearance; self-positioning of the employees; organization of the employees' spare 
time spending; workers' food; the attitude of the workers and the management to their work time; values of the company and the behavior norms, accepted there; development of the employees skills and their education; corporate and labor ethics; corporate ideology, etc.

In spite of the high level of interest to the phenomenon of "the culture of an organization" in modern sociology, neither sociology of management nor other sciences related to it (general management, social psychology, economics, and anthropology) have coined any general definition for this phenomenon.

The term "culture' is widely used in the modern language and mainly it has two meanings: the wide and the narrow ones. The wide meaning concerns the traditions, behavior norms and customs wide spread in a certain society and social institutes, including the economical sphere of life (Ustinova, 2014). The narrow meaning is referred to the sphere of creativity, moral and intellectual activity of people (Barulin, 2000; Berdyaev, 1999).

The widest approach to the term of culture is shown in the definition given in the "Big Russian Encyclopedia": "Culture is cultivation, education and breeding, development and respect - derived from the Latin "cultura", it's also a certain level of the development of a society, the level of personal creativity, which can be traced from the peoples' life styles their relations as well as from the material and spiritual products of their activity. As material results we can mention cars, buildings, as spiritual results we can mention results of cognition, works of art, norms of morality and the law. Culture also concerns peoples' skills, physical and intellectual abilities, realized in their activity (skills, knowledge, level of intellectual abilities, ethical and esthetical views, ideology, ways and forms of communication)". The given definition shows that culture is both the characteristic of a person and of his activity.

The classical definition of culture, which is connected with its' narrow meaning seems to be more actual. It was suggested by the outstanding English ethnographer E. Tylor in 1871. The definition sounds like this: "Culture is a complex, which includes people's knowledge, believes art, morality, laws, customs and traditions, as well as other kills and talents, acquired by people as constituent parts of a society" (Tylor, 1979). The given definition presupposes culture not just as a set of certain constituent parts, but as such a system, where all the parts are interrelated and interdetermined. All the parts (laws, customs, believes, skills) are arranged in the way, which allows us to see a culture as whole - in our case - a corporate culture.

Tylor's definition includes both cognitional (or intellectual) abilities of people and their motives and values, which form the basis of their actions (to this group we can refer ideology, morality, esthetical comprehension of life phenomena) along with their communicative abilities ("means and ways of communication"). Moreover all the elements in the Tylor's system of culture represent the sense of the whole structure, if we restrict the application of this definition only to the sphere of social live.

The greatest attention to the term of "the culture of an organization" is paid in management, which presupposes the character of the definitions given to it there. Such scientists as Vikhansky O.S. and NaumovA.I. consider corporate culture as a complicated system of values, namely, "a system of material and spiritual values, as well special activities, the interaction and interrelation of which is characteristic of a certain company and expresses its' individuality in selfpositioning and understanding its' partners. This individuality is expressed in the behavior, interactions of the company as a whole and the interactions between its' employees, as well as in the way of self-perception and the perception of the business environment" (Vikhansky, Naumov, 1999).

The functional definition of corporate culture is given by S.A. Lipatov: "corporate culture is a kind of collective programming of people's minds, which distinguishes one group of people from another. Taken in this sense corporate culture is a system of collective values (Lipatov, 2000). This approach to the problem of corporate culture is also accepted by I.P. Volkov. For him corporate culture is "a pattern of basic collective ideas, acquired by a group of people in the process of their adaptation to the changing environmental conditions and group integration, the efficiency of which is such, that it's considered enough valuable to be inherited by the new members of the group as the proper system of understanding and consideration of such problems" (Volkov, 2001).

$\mathrm{K}$. Davis and V. Lastovka believe that corporate culture plays a regulative role in the life of an enterprise and thus define it as "a set of norms, rules, customs and traditions, supported by the subject of organizational power , which create the frames of the normal behavior of the employees, corresponding to the strategic goals of a company" (Davis, 2000). For V. Lastovka corporate culture is "a set of values, opinions, ideas of morality dominating among the staff of a certain enterprise, as well as a certain psychological environment, which help the employees understand the mission of their company (the sense and the goals of their activity) its' functional mechanism, thus creating certain norms of the staff members' behavior and the system of ways to apply these norms in everyday life" (Lastovka, 2000).

M.N. Pavlova considers corporate culture with the help of the understanding of culture as a special social phenomenon: "the root of culture is a cult - a way of worshiping, believes and rituals. The general symbol of culture is a complex or a combination of regulations and a soul, which is open to accept them" (Pavlova, 1995). 
The notion of corporate culture ("the culture of an organization") became widely used in the management science in the late 1970-ths. It drew much attention of first western and then Russian sociologists. But despite the great interest to this phenomenon shown by the sociologists working in the spheres of the sociology of management, culture and spiritual life, its' complex understanding has not been found yet. But its' close connection with labor processes ( in the aspects of the staff solidarity, the efficiency and quality of work) is undoubted.

Considering the content structure of the term "corporate culture" the authors of the given article have analyzed more than 70 definitions of this term, suggested by the scientists in the period of 1979-2009. The results of the analysis allowed to make the conclusion of the content transformation of this term. (See picture 1)

\begin{tabular}{|c|c|c|}
\hline $\begin{array}{r}\text { Key eleme } \\
+ \\
\end{array}$ & $\begin{array}{l}\text { concept of "organizational } \\
\text { definitions) }\end{array}$ & sed on content analysis of \\
\hline $1979-1988$ years & $1989-1999$ years & $2000-2009$ years \\
\hline $\begin{array}{l}\text { 1. Shared } \\
\text { 2. The members of the } \\
\text { organization } \\
\text { 3. Values } \\
\text { 4. Organization } \\
\text { 5. Beliefs } \\
\text { 6. Behavior }\end{array}$ & $\begin{array}{l}\text { 1. The members of the } \\
\text { organization } \\
\text { 2. Organization } \\
\text { 3. Shared } \\
\text { 4. Values } \\
\text { 5. Behavior } \\
\text { 6. Sample }\end{array}$ & $\begin{array}{l}\text { 1. The system (a set) } \\
\text { 2. The members of the } \\
\text { organization } \\
\text { 3. Organization } \\
\text { 4. Values } \\
\text { 5. Behavior } \\
\text { 6. Shared noms }\end{array}$ \\
\hline
\end{tabular}

Picture 1. Rating of the key elements of the term "corporate culture" based on the results of the analysis of its' definitions.

The results of the content analysis show that modern scientists understand corporate culture, firstly, as a system (in the definitions given in the period of 1979-1988 it was considered a set of constituent parts). Secondly, the process of accepting the values of corporate culture is understood not as an individual phenomenon, but as a pan element of a group life. Thirdly, modern definitions often use such words as "strategy"," guideline", "inner and outer environment", which shows how important corporate culture is for the normal functioning and development of a company.

Using the common components of most of the definitions, we come to the following understanding of the phenomenon of corporate culture. It's a formal or a partially formal system of values and norms of behavior at work, as well as of rules customs and traditions, accepted and shared by the members of the staff, which was created in the process of their cooperative work, aimed at the fulfillment of the mission of the organization and achieving its' goals.

The authors of the article note that many of scientists take notions "culture of an organization" and "corporate culture" as equal things. N.A. Chizhov, for example, uses the term "the culture of an organization" (or corporate culture), which he understands as " norms of behavior, ideas and values, considered rules, regulating the ways of people's work and behavior in a certain company" (Chizhov, 2009). G.R. Lutfullina and O.N. Gromova understand these terms as synonyms, considering corporate culture as philosophy and values of a company ideas and traditions, accepted by the employees, style of work and the inner environment of a company. V. V. Kozlov, though finding some incoincidences in the meanings of these terms, considers them as quite similar notions (Kozlov, 2009).

To see the difference between the culture of an organization and corporate culture we should analyze the content structure of the terms "organization" and "corporation".

Analyzing the works of western sociologists we can see that there are different approaches to the understanding of an organization as a kind of social community. An organization (from Lat. "organization" - "make rational", " arrange") is understood as a complex including a group of people, a set of roles they perform in the group and other interrelated elements, important for achieving certain goals. Secondly, an organization is understood as a structure coordinating the activity of two or more people by means of the distribution of duties and hierarchization of power with the aim to achieve certain goals. Thirdly, an organization is a way of corporate activity of people, when it is represented in the form of a rigidly arranged, coordinated and targeted interaction (Milner, 2007).

A corporation is a community, a union, a group of people, united by their common professional, social and other interests and shared ideas (Garabajiy and Ustinova, 2013). A similar definition was suggested by O.S. Vikhansky and A.I. Naumov: " A corporation as a type of social organization is an enclosed group of people with a limited access, a maximal centralization of management and an authorized type of leadership, which opposes itself to all other social groups on the basis of its' corporate interests"(Vikhansky, Naumov, 1999).

The analysis of the given definitions shows that the main part of the content structure of the notion "organization" are the shared goals of corporate activity, while interests make the key point of the idea of a corporation. Aims of an 
organization are determined by its' top management and is accepted by all the staff without any doubts or contradictions. But interests are quite different as they are formed arbitrarily and without any influence from the point of the company's management. A. Smirnova is quite right sating that "interests are caused by the cognitive needs and the characteristics of personal orientation of people. In the process of cognitive activity interests do not disappear, moreover, they become the basis of new interests, which correspond to the new, higher level of cognitive activity. Personal interests have the property of growing into stable personal needs, a more active attitude to the world, and sometimes, into propensities" (Smirnova, 2009).

Summering it all up, the authors have come to the conclusion that the investigated notions are, firstly, different in their content structure, and secondly, there are interrelated and interdetermined. A culture of an organization may serve as a basis for forming and developing a corporate culture, while a corporate culture may be considered as the highest level of the development of the development of the culture of an organization.. This idea can be proven by the definition given by I.A. Smirnova "a corporate culture is the highest level of the development of an organization's culture which is revealed in the active role sense systems play in it, which allows the staff to willingly accept corporate mission, its' values, traditions, norm and rules, regulating the behavior, activity, communication between the employees, as well as their relations" (Smirnova, 2009).

Corporate culture is a set of suppositions accepted by the majority of the employees of a certain companies without any proves. These suppositions may have either been borrowed from the experience of other organizations solving similar problems or accidentally discovered in the process of work or acquired in any other way in the process of the company's attempts to adapt to the environment; but what is important they all have been considered efficient and worth being fixed in the company's experience and to be inherited by the new generations of employees (Spivak, 2001).

The problem of corporate identity of the staff of Russian companies becomes very actual due to to its' dualism. On the one hand, the necessity to create the favorable conditions for creating corporate identity is evident. On the other hand, activities aimed at the formation and development of corporate culture are considered things of the second or the third importance by most of the top managers, though such actions could motivate the staff identify themselves with a certain company and share its' goals and values (Juice, Shilova, 2013).

Corporate identity (from Lat. "corporatio" - "a union" and "identic" - "similar", "the same") is self-understanding and self-positioning of the members of the staff of the whole company or of the members of its' structural parts as inseparable parts of the organization, accepting its' philosophy, values and norm of behavior (Kupriyanov, 2012). It characterizes the special feeling of the employees belonging to one and the same company and presupposes emotional attachment of a person to the community he or she belongs to ( a social group or a group of colleagues at work) and a well formed goal this group or community wants to a achieve.

In foreign literature on sociology and management the term "corporate identity" is usually interpreted as "boundless emotional attachment of the employees to the organization they work at" (March, Simon, 1958). At the same time most of the researchers find it necessary to consider the correlation between corporate identity and such variables as motivation, satisfaction at work, qualification level of the employees, the position of workers. A great attention is paid to the understanding of the influence of the corporate identity of the staff on the general efficiency of enterprises (Riketia 2005), R. Van Dick(Van Dick et al, 2003) , W. Wagner, J. Shteilmacher , F.A. Mael and B.E. Ashforth (Mael, Ashforth, 1992), J. Lipponen (Lipponen, 2001).

Corporate identity of the staff of Russian companies has been the object of the research of many Russian sociologists beginning from the late 1990-th A.N. Krylov (Krylov, 2004), N.Yu Pimenova (Pimenova, 2004), S.A. Kupriyanov (Kupriyanov, 2012), A.N. Silin, N.G.Khairullina (Silin and Khairullina, 2004), O.V. Ustinova, R.S. Uteshev (Ustinova and Uteshev, 2014), L.M.Gaisina (Gaisina, 2014)). Special attention is paid to the functions of corporate identity of the staff as well to the internal factors of its' formation (Bondarenko,Gareev, Yakovleva, 2008).

\section{Methodology}

So that to investigate the peculiarities of the corporate identity formation the authors of the given article have held several polls of the staff of some big retailing companies (further they'll be named simply companies).At the first stage 252 employees of the company "Most" took part in the poll, at he second stage 120 employees were involved in this process.

A great share of the staff of the company is represented by the employees of the age less than 30 (See picture 2). The amount of the employees with the work period less than 1 year comprises more than $60 \%$. 


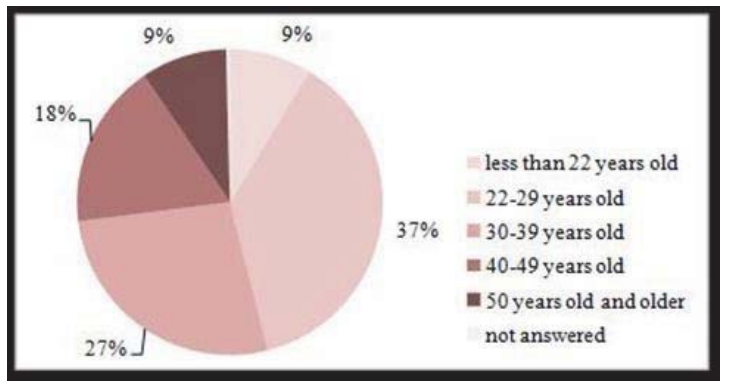

Picture 2. Age of respondents \%

Questions in the first questionnaire were arranged in 3 blocks:

- "Open questions"- the employees could express their opinion on the problem discussed. The answers on such questions were grouped and coded at the stage of processing. The results are shown as shares of the whole amount of respondents having answered these questions in the poll.

- Dichotomous questions -there were two possible answers on the questions (yes/no). Results are shown as the shares of the respondents, who have answered such questions and chose a certain variant of the answer.

- Scale type questions. Most of the questions have got the 4-level scale of the levels of agreement to the statements given (absolutely agree/ tend to agree/tend to disagree/ absolutely disagree). The answers to such questions are shown as orderly variables.

While analyzing the data got all the answers were arranged according to one uniform index, called "the index of agreement. It was done so to make process of comparison of different indexes.

\section{Results}

Let's consider the results obtained in more details.

\subsection{Moral and psychological climate in the company. Team relationships.}

Considering team relationships we can say that the most positive attitude is shown to the process of the newcomers' adaptation, team solidarity and initiative encouraging. The most critical attitude was shown to such parameters as professional skills, staff responsibility and distribution of duties among the staff members. In these cases the "index of agreement" is less than $75 \%$ (See picture 3).

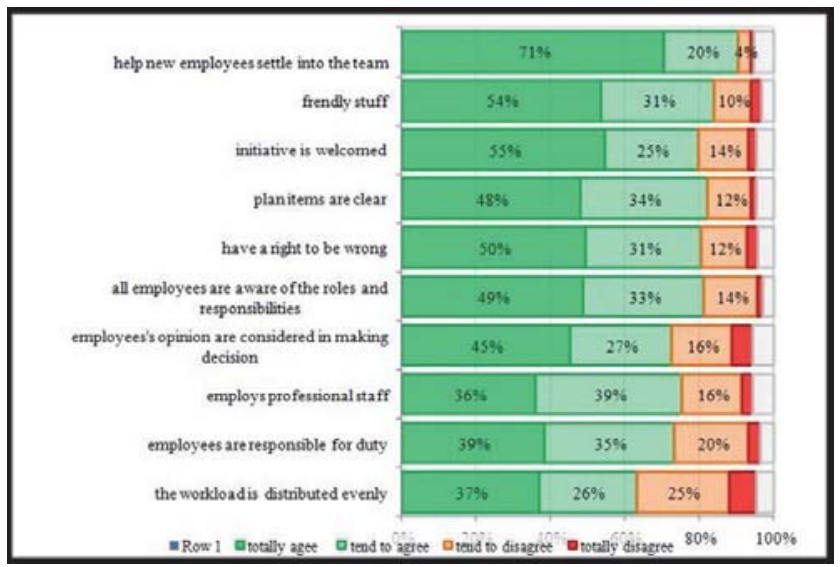

Picture 3. The employees' estimation of the work of their group or department 
The results of the general estimation of the interrelations in company show that the employees' attitude towards each other is mostly positive. Only $3 \%$ of the respondents are dissatisfied with the atmosphere in the company. (See picture 4).

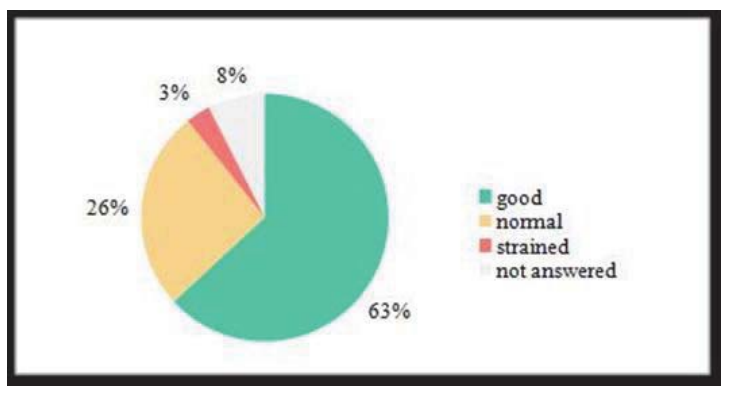

Picture 4. Interrelations between the staff members $\%$

The amount of workers, the proper training of the staff as well stability of teams are considered the leading factors of the increase of the efficiency by the employees-respondents. They have also mentioned the necessity of the improvement of working conditions and more reasonable organization of work. These are the factors influencing the level of the employees' satisfaction at work and the comfort ability of the atmosphere at the company. The employees show little interest in the relations with other groups and departments as well as in the state of the equipment they use. (See picture 5).

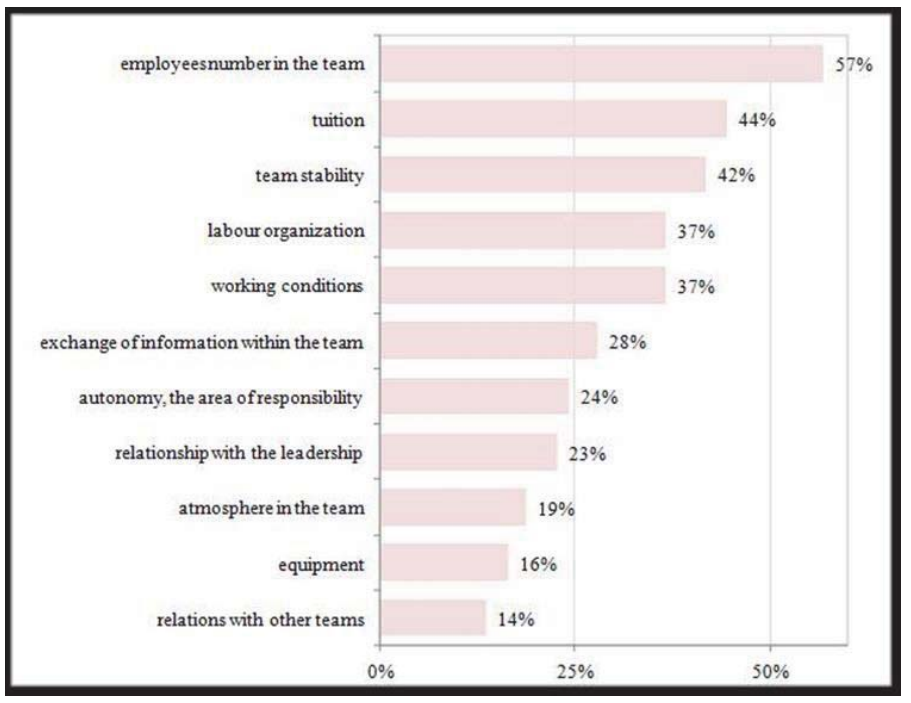

Picture 5. Factors influencing the increase of the efficiency of the team work

\subsection{Estimation of the immediate supervisors' work}

Generally the work of the company's management is considered as not much effective. But the amount of those who are absolutely dissatisfied with the management does not excess the figure of $5 \%$. The highest estimation the managers have got for their accessibility and negotiability, their trust to the team, and effective interaction with the subordinates. But the ability of the management to promote and provide god professional training the staff members is considered to be low.

The least satisfaction the employees show considering the participation of the management workers in the general 
team work and the way they motivate their subordinates by doing their own work and by their attitude to their duties. This shows the lack of authority of the management among the staff of their teams. (See pic.6).

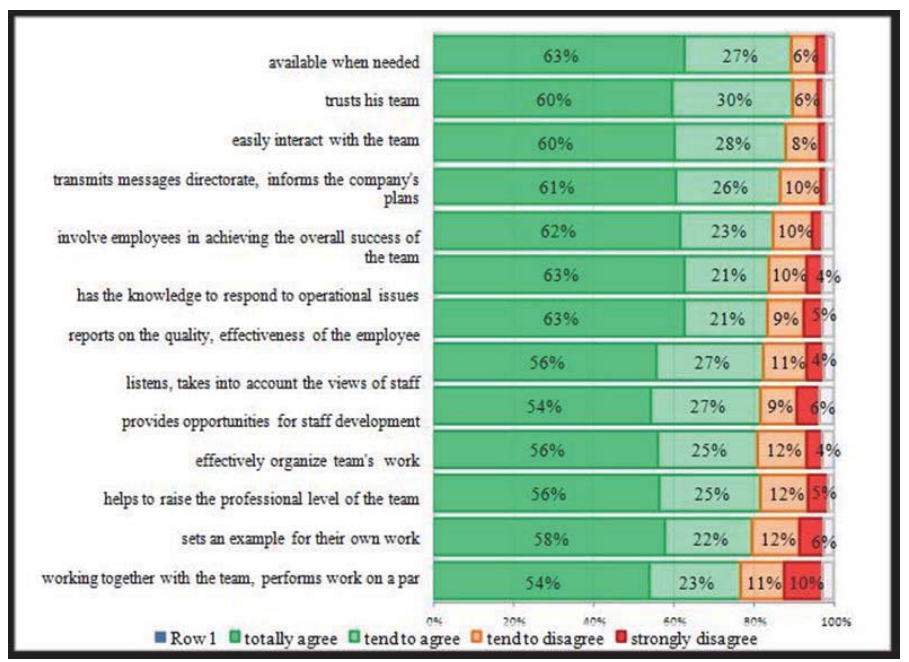

Picture 6. Estimation of the immediate supervisors' work (managers' work) \%

The majority of the employees consider their relations with the managers as normal and good (92\%). Only $2 \%$ of the respondents are dissatisfied with their relations with the managers (See picture 7).

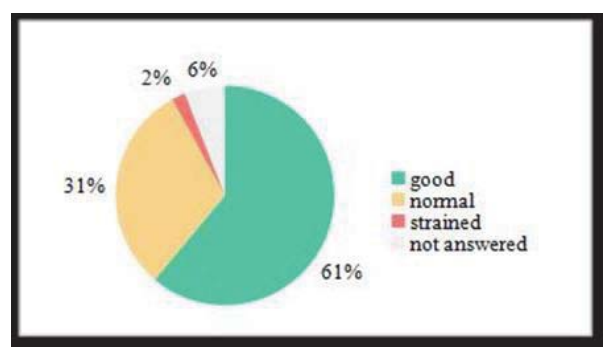

Picture 7. Relations between the managers and the staff of the company $\%$

$61 \%$ of the respondents absolutely trust all their managers' decisions; only $12 \%$ of them doubt the managers' decisions (See picture 8). It's important to note that the general analysis of the respondents' answers shows a low level of the company workers' trust in those who rule them and a low general estimation of the company's management.

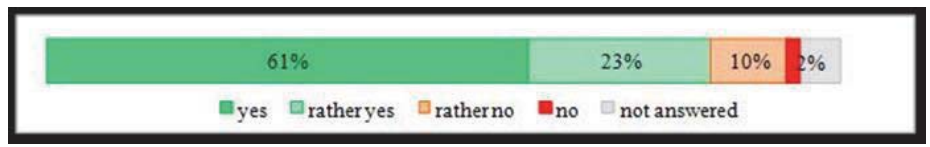

Picture 8. The level of the workers' trust in the management's decisions, \%

\subsection{The level of acceptance of the corporate values and corporate culture by the workers}

About $88 \%$ of the respondents consider corporate values important. But this idea is less spread among the management of the company than among ordinary company employees (See picture 9). 


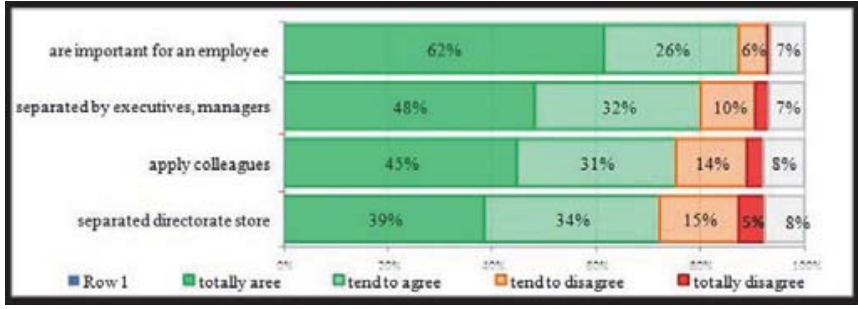

Picture 9. The level of corporate values acceptance in the company $\%$

The qualities in the best way characterizing the culture of the company are simplicity of communication, honesty and mutual trust in the relations between the employees. The second and the third place in this hierarchy occupy mutual respect and responsibility- that is the choice of about $1 / 3$ of the respondents. The qualities least characteristic of the corporate culture of the company are ethics, enthusiasm and dynamism- the choice of less than $15 \%$ of respondents (See picture 10).

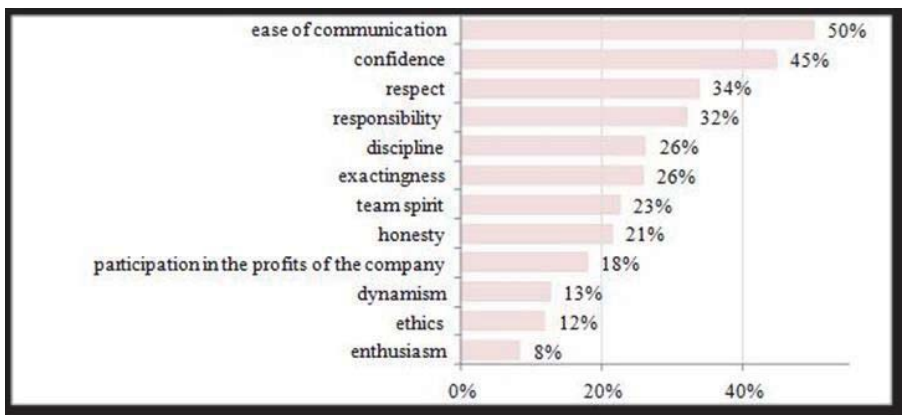

Picture 10. The basic qualities of the corporate culture $\%$

\subsection{The employees' estimation of additional means of motivating the staff}

Most of the employees think that they understand the processes and the criteria of the estimation of the results of their work (76\%). But they are least informed about the criteria of getting bonuses- $28 \%$ are not informed about the rules and the criteria of getting bonuses before they get them (See picture 11).

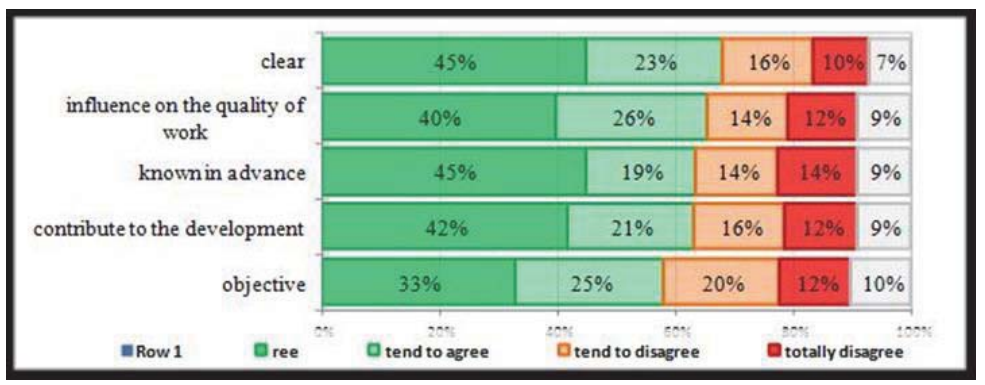

Picture 11. Employees' estimation of the procedure of the bonuses accrual, \%

Considering their feelings at work $45 \%$ of the respondents think of themselves first of all as of the members of the company. A big amount of the employees (21\% of the respondents) position themselves as a part of a team. (See picture 12). 


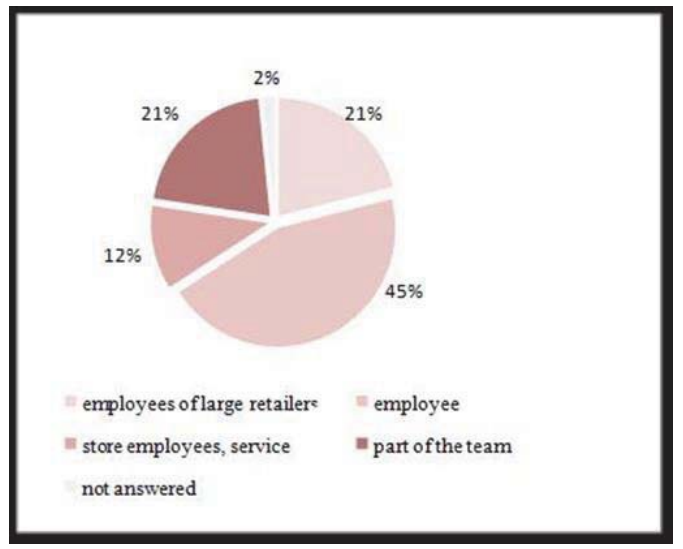

Picture 12. Self - identification of the members of the company's staff, \%

$80 \%$ of the staff is proud of working at the company. The amount of people ready to recommend the work at the company according to the program "A perspective specialist" comprise $76 \%$ of the whole amount of respondents.

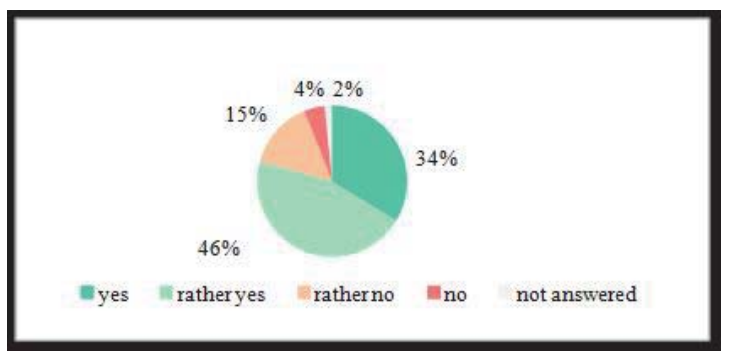

Picture 13. The level of pride to work in the company, \%

The estimation of the quality of professional activity shows the average level. The respondents are the most critical when considering the work they are doing as the best career choice for an employee. Only a few of the respondents consider the work they have to do something that suits them perfectly (See picture 14).

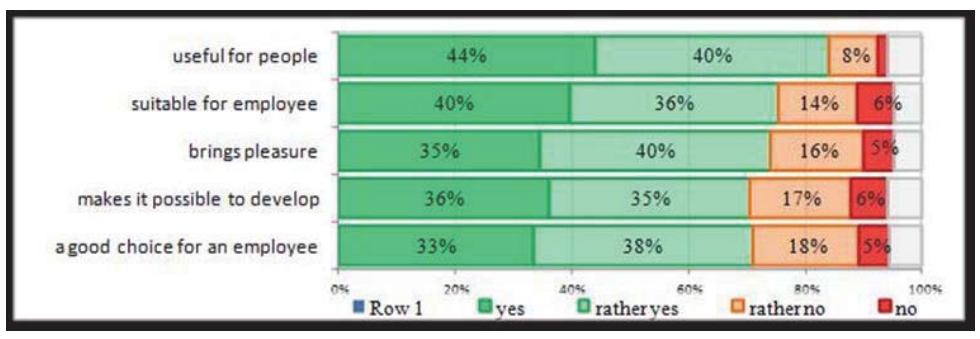

Picture 14. Estimation of the professional activity in the company, \%

\subsection{Motivation of the proper labor behavior}

This aspect of the corporate culture formation is based on the personal aspirations and values, which direct people's activities and determine the forms they may take. Judging by the results of the research the need to work is the basic 
factor of motivation for $80,2 \%$ of the respondents, every sixth of them "tended to agree" that it was the main stimulus to work $(14,7 \%), 4,3 \%$ of the poll participants found it difficult to answer the question about what is the basic motivation for them to work.

The salaries and other payments make one of the important factors, motivating the workers, as people normally want to be justly estimated at work and to be awarded according to their achievements. The salaries people get should allow them to satisfy their material and spiritual needs and correspond to their values. Material interest is one of the most powerful motivating aspects of human activity. So, $83,3 \%$ of the respondents say that a high salary is an important factor stimulating them to fulfill their duties, every tenth of them "tended to agree" that material aspects of work make an important part in their professional life, and the negative answer was got from 2,5\% of the respondents. It's interesting to note that almost nobody had a trouble with answering this question.

The other common motives are: health and good up-breeding of children ( $95,0 \%$ of positive answers), family wellbeing, the health of the employees themselves, proper rest, communication with relatives and friends $(90,9 \%$ of positive answers at each of the positions).

Career and promotion at work are not relevant for $18,3 \%$ of respondents, though nowadays career planning and career management, doth in theory and in practice, have become a very important thing in many companies. The understanding that a person can get first one post, the second and then the third should make him more self assured and provide him with the feeling of stability and control over the professional situation. Unfortunately, actually, only a few of big and stable companies can't guarantee such conditions to their employees. A little more than a half of the total amount of the respondents $(64,2 \%)$ have said that career promotion is important for them; every fifth of them has said that he is not interested in being promoted; only 1,75 of the respondents found it difficult to answer the question about promotion as a motive for their professional activity (Gaisina, 2014).

At the same time four fifth of the respondents consider respect and acceptance very important for them (81,7\%), only $2,2 \%$ of the respondents don't think it necessary to be approved at work. $0,8 \%$ of the employees were not sure to estimate how important the colleagues' attitude is for them.

The results of the poll have shown that such criteria as proper rest, communication with relatives and friends, the health of the employees themselves, the health and good breeding of children greatly influence the employees' behavior in the company. Health and rest are important for the vast majority of the employees, as well as the health and the breeding of children, all of them being the most important values for all the Humanity. Along with the mentioned factors, family well-being also plays a very important part in the life of the employees. Only 0,85 of the respondents found it difficult to say if family well-being is really a value in their lives (Valitova, Khairetdinov, 2014).

Let's consider the motives and stimuli to work relative to the qualification of the members of the staff. The respondents could choose 5 variants of answers, depending on the importance of the criteria mentioned. The hierarchy of the motives chosen looks like this:

1. Good relations with the colleague- $64,2 \%$

2. Convenient location of the enterprise $-56,12 \%$.

3. Good relations with the company's management $-35,8 \%$.

4. Just payment, based on the real results of work - 30, $1 \%$.

5. Acceptance and approval of well done work and acceptance by the colleagues and the management - $26,8 \%$.

We have to note that the hierarchical position occupied by the employees seriously influence the difference in their answers. For example for the staff members occupying managing positions, such criteria of motivation as doing the work allowing to show independence as well to get approval and acceptance from the colleagues and the top management are very important. For the employees and specialists, occupying average positions, such factors as convenient locality of the company and good relations with the colleagues are very important. (See the table 1).

Table 1. Rating of the most important motives of effective work relative to the qualification and the position of the workers in the corporate hierarchy\% of the general amount of respondents.

\begin{tabular}{|l|c|c|c|}
\hline \multirow{2}{*}{ Motive } & \multicolumn{3}{|c|}{ The category of the staff member } \\
\cline { 2 - 4 } & Employees & Specialists & Managements \\
\hline Good relations with colleagues & 1 & 1 & 8 \\
\hline Convenient location of the company & 2 & 2 & 6 \\
\hline Good relations with the management & 3 & 2 & 3 \\
\hline Salary and payments based on the results of work & 5 & 3 & 5 \\
\hline Approval of well done work and acceptance by the colleagues and the management & 7 & 8 & 2 \\
\hline
\end{tabular}




\begin{tabular}{|l|c|c|c|}
\hline Flexible schedule of the working day & 4 & 7 & 0 \\
\hline Flexible distribution of duties & 9 & 4 & 10 \\
\hline Social benefits & 10 & 5 & 4 \\
\hline Work, allowing to show independence & 12 & 10 & 1 \\
\hline
\end{tabular}

Analyzing the results shown in the table we have come to the conclusion that the management of the company have better opportunities to satisfy their needs which are of the higher level than those of the ordinary employees and specialists of the company, for whom motives and stimuli of effective work are ranked in a different way (Khairullin , 2013).

\section{Discussion}

The results of the research done have revealed two main problems negatively influencing the process of formation of corporate identity of the staff. The analysis of the results of the investigation is based on the critical points in the "index of agreement" in the answers on each of the questions in the questionnaire. Besides the main topic of the research (corporate identity of the staff), as well as the short period of the company's being on the market were also taken into account.

The first problem is the low estimation of the immediate management by the employees. The poll's results have shown the low quality of the personal meetings between the staff members and the company's management and low efficiency of their interaction with the teams of the company's workers, as well the lack of the will of the managers to participate in the work of the salesrooms teams and their disability to involve the employees into the work aimed at the achieving the company's success, which can be caused by the lack of knowledge necessary for the proper team management.

The second problem is the inefficient system of education and training in the company. The poll's results show dissatisfaction of the employees with the possibilities of development and career promotion at work as well as with the whole system of education and training in the company. These two problematical aspects are interrelated as it's impossible to promote a person, who isn't properly educated.

\section{Conclusions}

In the context of the problem discussed in the article the aspects of the corporate culture management seem to be interesting as the greatly influence the processes of formation and maintenance of the corporate identity of the staff. Management of the corporate culture presupposes changes to be made in all the elements of the corporate identity formation, namely : the moral and psychological climate improvement; interrelations between the employees of the company; improvement of the communication between the departments of the company and the interaction between the employees and their immediate management; modernization of the system of education; improvement of the staff motivation; formation of corporate values, traditions image and culture. As corporate culture management is based on preliminary analysis and estimation the methodology suggested in the given article may be considered a possible basis to analyze the state of the corporate identity of the staff of any company and to reveal the problems in the corporate identity formation. Corporate culture management oriented at the formation of the staff corporate identity can increase solidarity in the company, improve the company's efficiency and the discipline at the working place as well as to motivate the staff at the achievement of the mutually important goals.

\section{References}

Barulin, V.S. Social philosophy (2000). Moscow (340p.).

Berdyaev N.A. Existential dialectic of the divine and the human. On appointmenthuman (1999). Moscow. M: Republic.

Bondarenko G.V., Gareev E.S., Yakovleva R.P. (2008). The ideology of modern business and corporate culture. Economics and Management: scientific journal, 4 (pp. 79-85).

Chizhov N.A. (2009). Director and staff: Connectivity Technology. Moscow. M: "Alpha-press", 580p.

Garabajiy V.A., Ustinova O.V. (2013). The organizational culture of the university as a factor of influence on the development of creative activity of students. // University science: theoretical and methodological problems of training specialists in the field of economics, management and law. / Proceedings of the International Scientific Seminar (December 17, 2012) Ministry of Education and Science. VPO "Tyumen State Oil and Gas University", pp.10-15.

Gaisina L.M. (2014). The structure of labor and staff motivation in companies of oil and gas complex// Proceedings of the higher 
educational institutions. Sociology. The Economy. Policy, 4 (43), pp. 68-71.

Gaisina L.M. (2014). Transformation of the personnel management system in terms of social change: the oil and gas complex of Russia. Ufa: "Oriental print", $224 \mathrm{p}$.

Juice N.A., Shilova N.N. (2013). System adaptation of new employees as a tool to improve the efficiency of labor // University science: theoretical and methodological problems of training specialists in the field of economics, management and law. / Proceedings of the International Scientific Seminar (17 December 2012). Ministry of Education and Science of the Russian Federation. VPO "Tyumen State Oil and Gas University." Tyumen, pp. 215-220.

K. Davis (2000). Organizational Behavior / Trans. from English. St. Petersburg, 187p.

Khairullina N.G. (2013). Personnel management services to enterprises and tourism. Textbook. Tyumen: Publishing House of the Tyumen State Oil and Gas University.

Kozlov V.V. (2009). Corporate culture. Moscow: Publishing House of the "Alfa-Press".

Krylov A.N. (2004). Corporate identity for managers and marketers. Moscow. M: "Publisher Icarus".

Kupriyanov S.A. (2012). Corporate identity employees business organizations in Russia: Author. dis. ... Cand. soc. Sciences: 22.00 .04 Social structure, social institutions and processes. Rostov-on-Don, $21 \mathrm{p}$.

Lastovka V.V. (2000). On the classification of value orientations // Pedagogical Gazette. Kemerovo, pp. 105-109.

Lipatov, S. A. (2000). Organizational culture: a conceptual model and methods of diagnosis. Organizational psychology. SPb.

Lipponen J. (2001). Organizational identifications: Antecedents and Consequenses of Identifications in a Shipyard Context. Helsinki.

Mael F.A., Ashforth B.E. (1992). Alumni and their alma mater: A partial test of the reformulated model of organizational identification /I Journal of Organizational Behavior, 13.

March J.G., Simon H.A. (1958). Organizations. N.Y.

Milner B.Z. (2007). Organization Theory. Moscow. M: "INFRA-M", 720p.

Pavlova M.N. (1995). Diagnostic techniques, the formation and development of organizational culture: Author. dis. ... Cand. soc. Sciences: 22.00.04 - Social structure, social institutions and processes. Moscow, 23p.

Pimenova N.Y. (2004). Features of corporate identity in distance learning system: the experience of the Vladivostok State University of Economics and Service // University Management: Practice and Analysis. Vladivostok, 5-6 (33), pp.163-172.

Riketia M. (2005). Organizational Identification: A Meta-Analysis // Journal of Vocational Behavior. Vol.66 (2).

Silin A.N., Khairullina N.G. (2004). Human Resource Management: A Handbook for human resource management for university students. Tyumen: Tyumen state Oil and Gas University.

Smirnova I.A. (2009). The corporate culture of the organization. Psycho-Akmeologichesky bases of formation and development. Moscow.

Tylor Sir Edward Burnett (1979) // New Illustrated Columbia Encyclopedia.

Ustinova O.V., Yteshev R.V. (2014) Conceptual bases of career management manager. // Bulletin of the

Surgut State Pedagogical University. Surgut, 2, pp. 219-222.

Ustinova O.V. (2014) Deformation of values system as a reason of demographic crisis in Russia. Life Sci J;11(8s):465-468] (ISSN:10978135). http://www.lifesciencesite.com. 102.

Valitova N.E., Khairetdinov I.A. (2014). The influence of stress factors on fire protection employees' job performance. Neftegazovoe delo, 12-1, (pp.168-172).

Van Dick R., Wagner U., Slelmacher D. (2003) / Christ O. The utility of a broader conceptualization of organizational identification: Which aspects realy matter? // Journal of Occupational and Organizational Psychology.

Vikhansky O.S., Naumov A.I. (1999). Management. Moscow. M .: Gardariki.

Volkov I.P. (2001). Primary production team: the structure and dynamics of the relationship // Organizational Psychology. St. Petersburg, $511 \mathrm{p}$. 